\title{
閉鎖型苗生産システムにおけるサツマイモ増殖体生産数と 電気エネルギ消費量に及ぼすトレイのセル容積の影響
}

\author{
藤原雅哉・門田太志・全 租 厚・古在豊 樹 \\ 千葉大学園芸学部
}

\begin{abstract}
Number of Sweetpotato Propagules Produced and Electric Energy Consumption in a Closed Transplant Production System as Affected by Cell Volume of a Tray

\author{
Masaya Fujiwara, Taishi Kadota, Changhoo Chun and Toyoki Kozal \\ Faculty of Horticulture, Chiba University, Matsudo, Chiba 271-8510, Japan
}

(Received March 11, 2003)

\begin{abstract}
Reduction in electric energy consumption is important for minimizing resources used for sweetpotato propagule production in a closed transplant production system. The objective of this study was to test whether or not an increase in cell volume of a tray can reduce electric energy consumption for sweetpotato (Ipomoea batatas (L.) Lam.) vegetative propagation in a closed transplant production system. Single node cuttings each with one unfolded leaf were used as propagules and grown for 18 days at cell volumes of $20,40,60$ or $80 \mathrm{~mL}$ with the same planting density of $643 \mathrm{~m}^{-2}$ in all treatments (number of cells per tray was 98). The number of harvestable propagules per stock plant did not differ significantly among cell volumes 6 and 10 days after planting, but increased with increasing cell volume 14 and 18 days after planting. The electric energy consumption per propagule for cell volumes of $20,40,60$ and $80 \mathrm{~mL}$ was $0.54,0.42,0.34$ and $0.26 \mathrm{MJ}$, respectively, corresponding to electricity costs of 2.2-2.4, 1.7-1.8, 1.4-1.5 and 1.0-1.1 Japanese Yen, respectively, 18 days after planting. Thus, increasing the cell volume of a tray is a useful method for reducing electric energy consumption per propagule for sweetpotato vegetative propagation in a closed transplant production system.
\end{abstract}

Keywords : electricity cost, Ipomoea batatas (L.) Lam., single node cutting, vegetative propagation

2003 年 3 月 11 日受付

\section{はじめに}

閉鎖型苗生産システム (Kozai, 1999) では，季節や 天候の影響をほとんど受けることなくシステム内の環 境を容易に調節できる。また害虫や病原菌に污染され ていない増殖体あるいは苗を生産するのに適してい る. 閉鎖型苗生産システムは, 温室や苗围などの開放 型苗生産システムと比べてシステム内を安定した環境
に維持しやすいので，苗の生育と環境条件の関係を定 量的に把握しやすい，苗生産方法を標準化できる，な どの利点がある.

他方，サツマイモなどでは，母株である植物体の一 部を増殖体（栄養繁殖で用いられる増殖のための最小 単位）として利用し，その増殖体を育成して得られた 植物体を次サイクルの母株として利用することを繰り 返すことにより，増殖体ひいては苗の生産数を増大さ せる. 従来, サツマイモの増殖には, 展開葉を 5〜7 枚

Corresponding author: Toyoki Kozai, fax : +81-47-308-8841, e-mail : kozai @ faculty.chiba-u.jp 
含む挿し穂が増殖体として用いられてきた。これに対 してKozai et al. (1997) は，閉鎖型苗生産システムを 用いることにより展開葉 1 枚を含む短節を増殖体とし て用いることが可能であり，それゆえ増殖速度を増大 できることを報告した（Fig. 1)。

閉鎖型苗生産システムにおいてサッマイモの増殖を 行った際の増殖体あたりの電力料金は現状でも苗の一 般販売価格と比べて小さい (Lok et al., 2002b) ものの, 今後, 増殖に関わる資源消費量を最小限にするために, 増殖時の電気エネルギ消費量をさらに低減することは 重要である.

育成期間が同じでありかつ環境条件も同じ場合, 閉 鎖型苗生産システムの電気エネルギ消費量は育成面積 に比例する. 従って, 栽植密度を高めても, 単位面積 あたり単位時間あたりの増殖体生産数が減少しなけれ ば増殖体あたりの電気エネルギ消費量を維持あるいは 低隇することができる (Lok et al., 2002a).ところが, 実際には，栽植密度を一定以上に高めると，母株あた りの増殖体生産数が減少するためにかえって増殖体あ たりの電気エネルギ消費量は増大する（Fujiwara et al., 2002). 従って, 電気エネルギ消費量をこれまでよ りもさらに低隇するためには, 高栽植密度でも増殖体 の生長を維持あるいは促進させる方法を見出す必要が ある。

トレイのセル容積の増大とともに植物体の生長は促 進される(例えば, Liu and Latimer, 1995 ; Oda et al., 2002）ことから, 閉鎖型苗生産システムにおける栽植
密度が高くても, セル容積の増大とともに母株の生長 を促進できれば，母株あたりの増殖体生産数を増大で き，ひいては増殖体あたりの電気エネルギ消費量を低 減できる可能性がある。 セル容積が, 閉鎖型苗生産シ ステムにおいて育成したサツマイモセル成型苗および その定植後の生長量に及ほす影響を調べた報告 (He et al., 2000 ; Islam et al., 2002)・はあるが, 増殖体生産数 と増殖時における電気エネルギ消費量に及ほす影響を 調べた報告はみあたらない. 本研究では, サツマイモ 増殖時における閉鎖型苗生産システムの電気エネルギ 消費量を低隇することを目的として，一定の栽植密度 下におけるセル容積が母株あたりの増殖体生産数と増 殖体あたりの電気エネルギ消費量に及ほす影響につい て検討した。

\section{材料および方法}

\section{1. 供試材料および增殖体育成条件}

白色螢光灯下で育成したサッマイモ（Ipomoea batatas (L.) Lam., 品種：ベニアズマ）植物体（展開 葉：3４ 枚, 生体重：4～5 g) から, 展開葉 1 枚を含 む短節 (乾物重: $86 \pm 8 \mathrm{mg}$, 葉面積: $22 \pm 5 \mathrm{~cm}^{2}$ ) を切 り出して増殖体とした。容積が $20,40,60$ および $80 \mathrm{~mL}$ となるように市販のポット（アイポット，福岡丸本 (株), 容積：115 mL) の上部を切除した容器をセル (Fig. 2, Table 1) とした。市販の培地（スミリンセル 培土，スミリン農産工業 (株)) を充填したセルに増殖 体を 1 個体ずつ植え付けた後, 植え付け日を 0 日目と

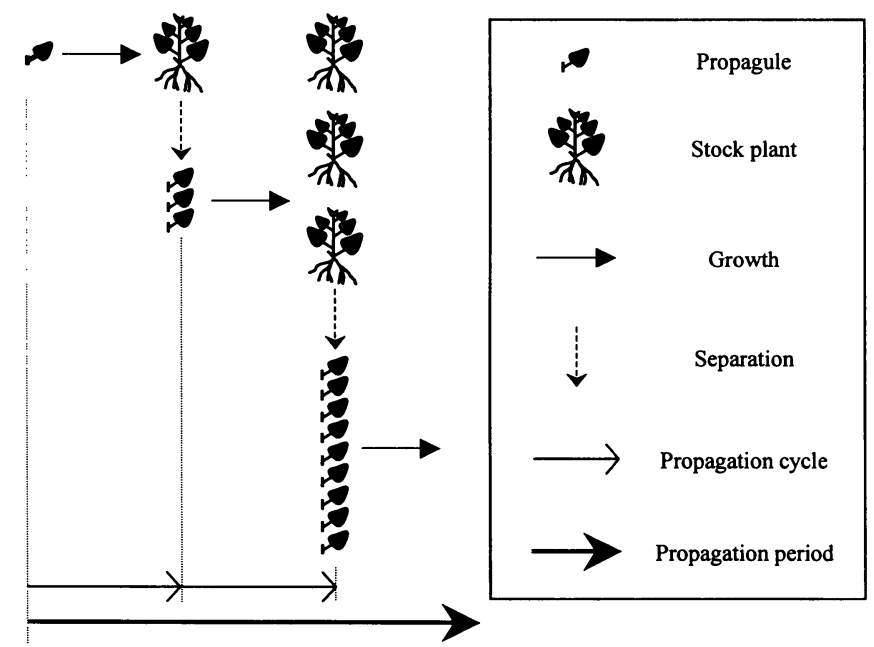

Fig. 1 Schematic diagram of a vegetative propagation method that uses single node cuttings, each with one unfolded leaf, as propagules. 


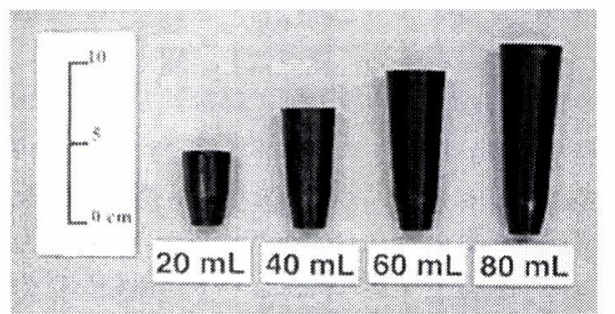

Fig. 2 Photograph of cells at four levels of volume used in the present experiment. Planting density was the same for all treatments at $643 \mathrm{~m}^{-2}$ (number of cells per tray was 98).

Table 1 Volume, depth and diameter of cells at four levels of volume used in the present experiment.

\begin{tabular}{ccc}
\hline $\begin{array}{c}\text { Volume } \\
(\mathrm{mL})\end{array}$ & $\begin{array}{c}\text { Depth } \\
(\mathrm{cm})\end{array}$ & $\begin{array}{c}\text { Diameter } \\
(\mathrm{cm})\end{array}$ \\
\hline 20 & 4.4 & 2.8 \\
40 & 7.3 & 3.1 \\
60 & 9.7 & 3.4 \\
80 & 11.8 & 3.7 \\
\hline
\end{tabular}

Note: Planting density was the same for all treatments at $643 \mathrm{~m}^{-2}$ (number of cells per tray was 98 ).

して 18 日間生育させた. セルは栽植密度が $643 \mathrm{~m}^{-2}$ の トレイ (98 角プラグトレイ, $0.28 \mathrm{~m}(\mathrm{~W}) \times 0.55 \mathrm{~m}(\mathrm{~L})$, 日新農工産業 (株)）の各穴に設置した。充填する培地 の乾燥重量は, セル容積が 20, 40, 60 および $80 \mathrm{~mL}$ の とき，それぞれ $5.8 ， 12.0,17.6$ および $23.5 \mathrm{~g} /$ cell とし た。植え付け時の培地の体積含水率は, いずれの試験 区でも 70\%とした. 育成期間中の気温, 相対湿度, 光合 成有効光量子束, 明期, $\mathrm{CO}_{2}$ 濃度は, それぞれ $30^{\circ} \mathrm{C}$, $75 \%, 100 / 200 / 300 \mu \mathrm{mol} \mathrm{m}^{-2} \mathrm{~s}^{-1}(0-4 / 5-9 / 10-17$ 日目), $16 \mathrm{~h} \mathrm{~d}^{-1}, 1000 \mu \mathrm{mol} \mathrm{mol}{ }^{-1}$ に設定した. 0 日目には水 を底面から与えた。 0 日目以降は, 明期開始時における 培地の体積含水率が $40 \%$ 以下のときに, 底面から液肥 (大塚八ウス肥料 1 号：1.5 $\mathrm{g} \mathrm{L}^{-1}$ および 2 号：1.0 g $\mathrm{L}^{-1}$ の混合液, 大塚化学 (株)) を与えた。 なお, 体積 含水率が $40 \%$ ときではまだ培地の乾燥は認められな かった.

\section{2. 育成装置}

育成装置としてグロースチャンバ（コイトトロン KG-150MJA 型, 小系工業 (株), $1.7 \mathrm{~m}(\mathrm{~W}) \times 1.3 \mathrm{~m}$ $(\mathrm{L}) \times 1.9 \mathrm{~m}(\mathrm{H}))$ を用いた。装置内に 4 枚のトレイを
収納できる棚 $(0.6 \mathrm{~m}(\mathrm{~W}) \times 1.2 \mathrm{~m}(\mathrm{~L}) \times 0.4 \mathrm{~m}(\mathrm{H}))$ を 4 段設置した。

$32 \mathrm{~W}$ の高周波白色螢光灯 (FHF32EX-W, 松下電器 産業 (株)）を各棚に 8 本設置した。棚の天井および壁 面を反射シート (SU-115, 三井化学（株））で覆った. トレイ面上における光合成有効光量子束の調節には, ライトコントローラ (NQ21575-321，松下電工 (株)) を用いた. 赤外放射式 $\mathrm{CO}_{2}$ 分析計 (ZFP9, 富士電気 (株)), データコントローラ (Greenkit 100, (株) ESD), 記録・制御用ソフトウェア (DL-300，(株) ESD)，パー ソナルコンピュータおよび電磁弁（AB31-02-1，（株） CKD）を用いて装置内の $\mathrm{CO}_{2}$ 濃度の測定および制御 を行った。

\section{3. 測定および算定}

新たに伸長したシュートの展開葉の枚数およびその 葉身長を $6 ， 10 ， 14$ および 18 日目に測定した。この シュートが有する節のうち, その葉身長が $55 \mathrm{~mm}$ (植 え付け時に拈ける增殖体の葉身長の最小值）以上の葉 を有する単節を次サイクルの増殖体として利用可能と 判断して, 増殖体生産数を算定した。増殖体生産数は 母株あたりの值として算定した。母株の乾物重を 6, 10, 14 および 18 日目に, 生体重および葉面積を 18 日 目に測定した。母株を地上部（新たに伸長したシュー 卜と増殖体) と地下部に切り分け, $80^{\circ} \mathrm{C}$ で 72 時間以上 乾燥させた後, 乾物重の測定を行った。葉面積は, 葉 部の画像をカラーイメージスキャナ（GT-8500WIN, セイコーエプソン (株)) で取り込み, 葉面積測定用ソ フトウェア (LIA32 for Windows 95 ver. $0.374 \beta 2$, 山 本一清 (名古屋大学)) を用いて測定した。

育成期間中の照明器具の電気エネルギ消費量を, 簡 易型電力量表示器 (エコワット, 東光精機 (株)) を用 いて測定した。この測定值，および Ohyama et al. （2000）が報告した閉鎖型苗生産システム全体（照明器 具, 空調器具および室内設備) の電気エネルギ消費量 に対する照明器具の電気エネルギ消費量の比 (0.76) か ら, 育成期間中のシステム全体の電気エネルギ消費量 を算定した. Ohyama et al. (2000) の実験では, 閉鎖 型苗生産システムは環境制御を行っていない部屋内 に, 空調器具の室外機は気温 $18 \sim 20^{\circ} \mathrm{C}$ に制御されて いる室内にそれぞれ設置されている. 東京電力（株） の低圧電力契約 (基本料金：1020 円 $/ \mathrm{kW}$, 電力量料 金：10.6円/kWh (夏季), 9.6 円 $/ \mathrm{kWh}$ (その他季) ) に あてはめて電力料金を試算した。試算にあたり，1)燃 料費調整および消費税は考慮しない，2)力率割引およ 
び割増は考慮しない，3）一か月は 30 日間である，と した。

育成期間中, 明期開始時ごとにトレイ（セル，培地， 母株を含む）の重量を測定した。トレイの重量，セル の重量, 培地の乾燥重量および母株の生体重から, 毎 明期開始時における培地の体積含水率を算定した。毎 明期開始時における母株の生体重には，予備実験で把 握した生体重を用いた。予備実験に用いた育成装置な らびに装置内の環境条件は本実験のそれらと同じであ る. かん水前後のトレイ重量からかん水量を算定した. 育成期間中に与えた窒素, リンおよびカリウムの量を, 培地に含まれるそれらの量とかん水により与えたそれ らの量の和から推定した，培地に含まれる量は，乾燥 培地内の濃度 (窒素: $0.3 \mathrm{mg} \mathrm{g}^{-1}$, リン: $2.5 \mathrm{mg} \mathrm{g}^{-1}$, カ リウム：0.1 $\mathrm{mg} \mathrm{g}^{-1}$ ) およびセルに充填した培地の乾燥 重量から推定した。かん水により与えた量は, 液肥内 の濃度 (窒素: $259 \mathrm{mg} \mathrm{L}^{-1}$, リン: $53 \mathrm{mg} \mathrm{L}^{-1}$, カリウ ム: $\left.297 \mathrm{mg} \mathrm{L}^{-1}\right)$ およびかん水量から推定した。

実験を 3 回繰り返した。繰り返した実験のそれぞれ を反復と見なし，平均値および標準誤差を算定した。 サンプル数は 1 回の測定につき試験区あたり 16 とし た. 統計分析ソフトウェア (SigmaStat for Windows ver. 2.03, SPSS Inc.) を用いて分散分析法および回帰 分析法により検定を行った。

\section{結果および考察}

\section{1. 增殖体生産数}

増殖体として利用可能な葉が出現し始めた後，日数 の経過とともに母株あたりの増殖体生産数はほぼ直線 的に増大した (Fig. 3). 増殖体生産数は, 6 および 10 日目では異なるセル容積の間で有意な差がみられな かったが, 14 および 18 日目ではセル容積の増大とと もに大となった。増殖体生産数の経日変化を, Kubota and Kozai (2001), Fujiwara et al. (2002) および Lok et al. (2002a，2002b) と同様に一次式を用いて近似で きた. 増殖体生産数を日数の一次関数として表した場 合の $\mathrm{x}$ 軸切片はセル容積の間でほほ同じだったが，傾 きはセル容積の増大とともに大となった，傾きがセル 容積の増大とともに大となったのは, 育成期間後半に おいて母株の葉の生長が促進されたためと考えた。

地上部（新たに伸長したシュートと増殖体）乾物重 は，6，10 および 14 日目では異なるセル容積の間で有 意な差がみられなかったが, 18 日目ではセル容積の増 大とともに大となった (Fig. 4). 一方, 地下部乾物重 は，6および 10 日目では 40，60および $80 \mathrm{~mL}$ がほぼ 同じで $20 \mathrm{~mL}$ よりも大となり，14 および 18 日目では

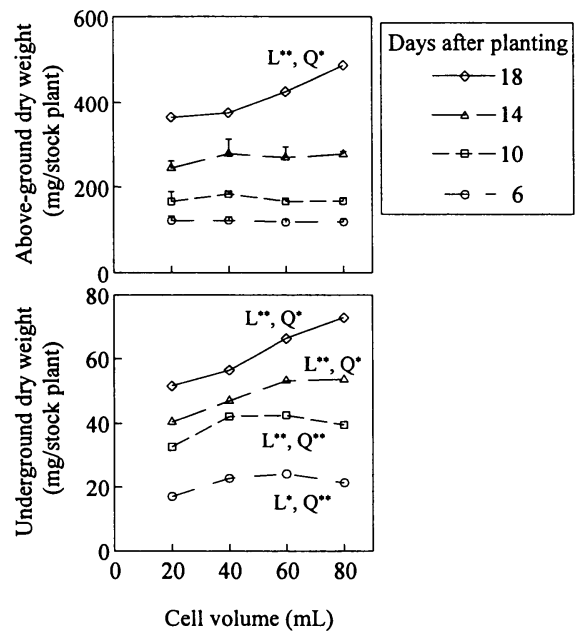

Fig. 4 Above-ground and underground dry weights of stock plants at four levels of cell volume. $\mathrm{L}^{\mathrm{NS}}$, $\mathrm{Q}^{\mathrm{NS}}, \mathrm{L}^{*}, \mathrm{Q}^{*}, \mathrm{~L}^{* *}, \mathrm{Q}^{* *}=$ nonsignificant or significant linear $(\mathrm{L})$ or quadratic $(\mathrm{Q})$ response at $\mathbf{P} \leq 0.05$ or 0.01 , respectively. Above-ground includes newly elongated shoot and explant. Vertical bars represent SE $(n=3)$ for observations where ANOVA did not indicate significant differences among cell volumes.

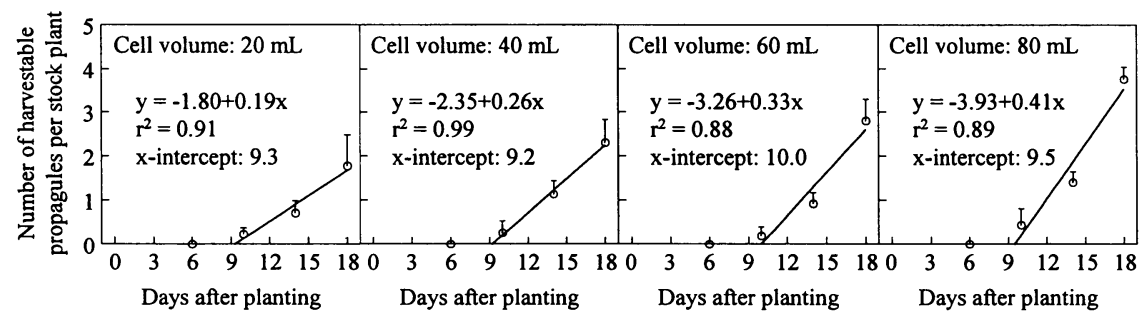

Fig. 3 Time courses of the number of harvestable propagules of stock plants at four levels of cell volume during the experiment period. Vertical bars represent standard error $(n=3)$. 
セル容積の増大とともに大となった. 18 日目における 母株の生体重および葉面積は, 乾物重と同様にセル容 積の増大とともに大となった（Table 2).

セル容積の増大による地下部乾物重の増大が日数の 経過とともに顕著となった後, 地上部乾物重も増大し たことから, 母株の生長量がセル容積の増大とともに 大となった主な理由は, 根圏の制限が減少したことと 考えられる. 根圈の制限により植物体の生長が抑制さ れるという報告は数多くなされ（例えば, Ruff et al., 1987 ; Ismail and Noor, 1996), その原因として植物成 長ホルモンの根における合成と根からの転流が抑制さ れることが示唆されている (Richards and Rowe, 1977 ;

Table 2 Fresh weight and leaf area of stock plants at four levels of cell volume 18 days after planting.

\begin{tabular}{ccc}
\hline $\begin{array}{c}\text { Cell volume } \\
(\mathrm{mL})\end{array}$ & $\begin{array}{c}\text { Fresh weight } \\
\text { (g/stock plant) }\end{array}$ & $\begin{array}{c}\text { Leaf area } \\
\left(\mathrm{cm}^{2} / \text { stock plant }\right)\end{array}$ \\
\hline 20 & 4.47 & 94 \\
40 & 4.96 & 105 \\
60 & 5.79 & 118 \\
80 & 6.78 & 140 \\
\hline $\mathrm{L}$ & $* *$ & $* *$ \\
$\mathrm{Q}$ & $* *$ & $* *$ \\
\hline
\end{tabular}

** Significant linear $(\mathrm{L})$ or quadratic $(\mathrm{Q})$ response at $\mathrm{P}$ $\leq 0.01$.
Carmi and Heuer, 1981)。ただし，このメカニズムは 未解明である. 今後, 根圏の制限により植物体の生長 が抑制される理由を明確にするために，このメカニズ ムの解明が期待される.

セル容積の増大とともに母株の生長量が大となった もうひとつの理由として, かん水回数が減少したこと があげられる. セル容積が $20,40,60$ および $80 \mathrm{~mL}$ の とき，それぞれ $11 ， 9 ， 6$ および 4 回かん水を行った。 セル容積の増大とともにかん水回数が減少したのは, 蒸発散に伴う培地の体積含水率の減少の割合が小さ かった(Fig. 5)ためである. Yabuki and Kitaya (1984) は, かん水後に培地内の $\mathrm{CO}_{2}$ 濃度が高くなることを報 告した.また, 培地内の $\mathrm{CO}_{2}$ 濃度が高いと純光合成速 度が低下し生長は抑制されることが，キュウリについ て報告されている (Kitaya et al., 1984)。これらのこ とから, セル容積が小さい, すなわちかん水回数が多 いほど, 培地内における $\mathrm{CO}_{2}$ 濃度の増大が頻繁に起こ り，その結果，母株の生長が抑制された可能性がある と考えた.

母株の体内に含まれる窒素の量を, Yoshida et al. (1970) や Hozyo et al.（1971）が報告したサツマイモ 植物体内の窒素濃度と本実験で育成した母株の乾物重 から推定し，この量と育成期間中に与えた窒素の量 (Fig. 6) を比較すると, 後者が前者の 1.9〜2.2 倍であっ た．同様の方法でリンおよびカリウムについても比較

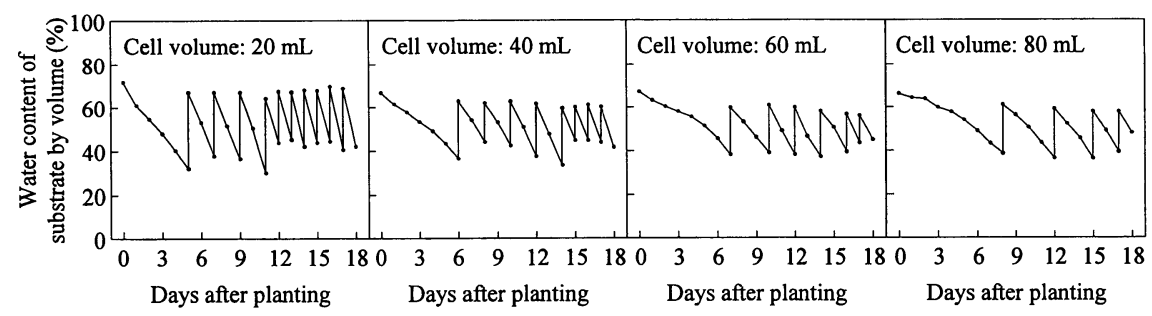

Fig. 5 Time courses of water content of substrate by volume at four levels of cell volume during the experiment period.

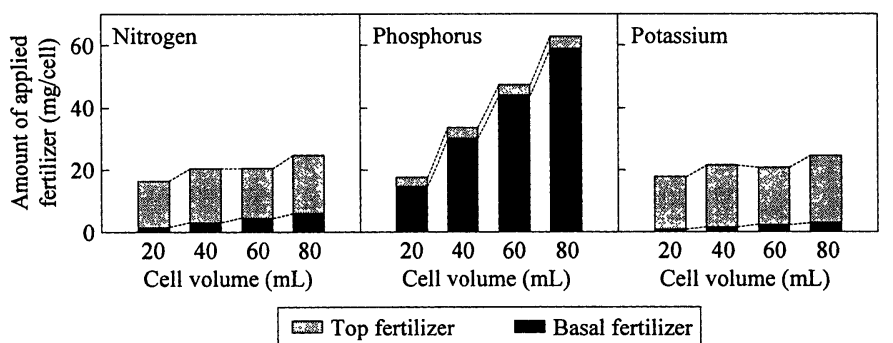

Fig. 6 Amounts of applied fertilizer at four levels of cell volume during the experiment period. 
すると, リンに関しては 22.8〜 55.9 倍, カリウムに関 しては $1.0 \sim 1.2$ 倍であった. セル容積の増大とともに 植物体の生長が促進される理由として施肥量が増大す ることが示唆されている (McConnaughay et al., 1993) ものの, 本実験の施肥量は, 母株の生長に必要な量と 比べて過剩だったと推測され, 生長の制限因子とは考 えにくい. また，育成期間中に与えた肥料のうち，リ ンの量はセル容積の増大とともに大となったが, 窒素 とカリウムの量は異なるセル容積の間で生長量にみら れたほどの顕著な違いがみられなかった。これらのこ とから, 本実験では, セル容積の間の施肥量の違いが 母株の生長には影響を及ほさなかったか, あるいは及 ほしたとしてもその影響は先に述べた二つの要因の影 響と比べて小さいと考えた。

\section{2. 電気エネルギ消費量}

育成期間中の照明器具の電気エネルギ消費量は 468 $\mathrm{MJ} \mathrm{m}^{-2}$ であった.この測定值より, 育成期間中の閉鎖 型苗生産システム全体 (照明器具, 空調器具および室 内設備) の電気エネルギ消費量を $616(=468 / 0.76) \mathrm{MJ}$ $\mathrm{m}^{-2}$ と算定した. 18 日目における増殖体あたりの電気 エネルギ消費量は, セル容積が $20,40,60$ および $80 \mathrm{~mL}$ のとき，それぞれ $0.54 ， 0.42,0.34$ および $0.26 \mathrm{MJ}$ (そ れぞれ電力料金 $2.2 \sim 2.4,1.7 \sim 1.8,1.4 \sim 1.5$ および 1.0〜 1.1 円）であった. 増殖体あたりの電気エネルギ 消費量は, セル容積が $80 \mathrm{~mL}$ のときの值が Fujiwara et al. (2002) および Lok et al. (2002a，2002b) が報告 したなかでの最も小さい值である $0.36 \mathrm{MJ}$ (セル容 積: $35 \mathrm{~mL}$, 栽植密度: $\left.840 \mathrm{~m}^{-2}\right)$ よりも約 $30 \%$ 小さ かった。

セル容積の増大とともにセルに充填する培地の量は 増大するが，これに伴う培地に関わる料金の増大は小 さい.メーカーにより公表されている培地の小売販売 価格 $(50$ 円 $/ \mathrm{L})$ を乾燥培地重量あたりに換算した值段 とセルに充媜した培地の乾燥重量から推定した, 増殖 体あたりの培地に関わる料金は, セル容積が 20,40 , 60 および $80 \mathrm{~mL}$ のとき, それぞれ $0.4,0.7,0.8$ および 0.8 円であった.これらの值と電力料金の和は, セル容 積が $20,40,60$ および $80 \mathrm{~mL}$ のとき，それぞれ $2.6 〜$ 2.7, 2.3〜2.4, 2.2〜2.3 および 1.8〜 1.9 円であった. な お, 培地を大量購入する場合の価格は小売販売価格よ りも安くなると見込まれ，培地に関わる料金はここで 推定した値よりもさらに安価になると考えられる.こ のように培地に関わる料金の増大の絶対量は小さいこ とから, セル容積を増大することは増殖体生産数を増
大する上で有効であると考えた。

前述した Lok et al. (2002a) の実験結果と本結果よ り, 閉鎖型苗生産システムの電気エネルギ消費量を低 減するためには, 栽植密度が高くかつセル容積が大き いトレイを用いることが適していると考えられる. 本 実験条件下で増殖体生産数が増大した主な理由は根圏 の制限の減少と考えられることから, 栽植密度を本実 験の密度より高めてもセル容積の増大とともに母株あ たりの増殖体生産数が増大する可能性は高いと考え た.

本実験では栽植密度を $643 \mathrm{~m}^{-2}$ としたが, 閉鎖型苗 生産システムではこれよりも密度を高めることで増殖 体あたりの電気エネルギ消費量を低減することができ る (Fujiwara et al., 2002). 栽植密度を本実験の密度 より高めても, セル容積の増大とともに母株あたりの 増殖体生産数が増大すれば, 増殖体あたりの電気エネ ルギ消費量を本結果よりもさらに低減できる可能性が あり,その場合には増殖体あたりの電力料金は本結果 の中の最小值である $1.0 \sim 1.1$ 円よりもさらに安価にな ると予想される.

本実験ではサツマイモの増殖時に着目したが，セル 容積の増大とともに苗の定植後の生育が促進される (Nicola and Cantliffe, 1996) ことから, 苗化時におい てもセル容積の増大による利点があると考えられる。 He et al. (2000) および Islam et al. (2002) が行った 実験では, セル容積の間 (35および $55 \mathrm{~mL}$ ) で圃場定 植後の塊根収量に顕著な差が認められなかったが, 検 討する幅を広くした場合にはセル容積の増大とともに 塊根収量が增大寸る可能性がある. しかし, 苗の輸送 コストが単位容積あたりあるいは単位重量あたりで決 まる場合, このコストはセル容積の増大とともに増大 すると考えられ, 今後, これらに関する知見を得る必 要がある.

\section{結論}

展開葉を 1 枚含む単節を増殖体として用い, セル容 積を $20,40,60$ および $80 \mathrm{~mL}$, かつ栽植密度を一定 (643 $\mathrm{m}^{-2}$, トレイあたりのセル数：98）として 18 日間生育 させた。母株あたりの増殖体生産数は，6および 10 日 目ではセル容積の間で有意な差がみられなかったが, 14 および 18 日目ではセル容積の増大とともに大と なった. 18 日目における増殖体あたりの電気エネルギ 消費量は, セル容積の増大とともに低減し, 容積が 20, 40，60 および $80 \mathrm{~mL}$ のときそれぞれ $0.54 ， 0.42 ， 0.34$ 
および $0.26 \mathrm{MJ}$ (電力料金それぞれ 2.2〜2.4, $1.7 〜 1.8$, 1.4〜1.5 および 1.0〜 1.1 円)であった. 栽植密度を本実 験の密度より高めても, セル容積の増大による母株あ たりの増殖体生産数の増大で, 増殖体あたりの電気工 ネルギ消費量を本結果よりもさらに低減できると考え た。その場合には，増殖体あたりの電力料金は本結果 の中の最小值である $1.0 \sim 1.1$ 円よりもさらに安価にな ると予想される。

\section{文献}

Carmi, A., Heuer, B. 1981. The role of roots in control of bean shoot growth. Ann. Bot. 48 : 519-527.

Fujiwara, M., Kubota, C., Kozai, T., Sakami, K. 2002. Number of sweetpotato propagules produced and electric energy consumption in a closed-type transplant production system under different number of cells per tray. (D212), Annual Meeting of Environ. Control in Biol., August, Tokyo, p 185.

He, D., Lok, Y. H., Chun, C., Kozai, T. 2000. Yield and growth of sweetpotato using plug transplants as affected by cell volume of plug tray and type of cutting. In "Transplant Production in the 21 st Century" (ed. by Kubota, C., Chun, C.), Kluwer Academic Publisher, Dordrecht, p 154-159.

Hozyo, Y., Murata, T., Yoshida, T. 1971. The development of tuberous roots in grafting sweet potato plants, Ipomoea batatas Lam. (Japanese text with English abstract) Bull. Natl. Inst. Agric. Sci. D 22 : 165-191.

Islam, A. F. M., Kubota, C., Takagaki, M., Kozai, T. 2002. Sweetpotato growth and yield from plug transplants of different volumes, planted intact or without roots. Crop Sci. 42 : 822826.

Ismail, M. R., Noor, K. M. 1996. Growth, water relations and physiological processes of starfruit (Averrhoa carambola L.) plants under root growth restriction. Sci. Hortic. 66 : 51-58.

Kitaya, Y., Yabuki, K., Kiyota, M. 1984. Studies on the control of gaseous environment in the rhizosphere (2) Effect of carbon dioxide in the rhizosphere on growth of cucumber. (Japanese text with English abstract) J. Agric. Meteorol. 40 : 119-124.

Kozai, T., Kubota, C., Heo, J., Chun, C., Ohyama, K., Niu, G., Mikami, H. 1997. Towards efficient vegetative propagation and transplant production of sweetpotato (Ipomoea batatas (L.) Lam.) under artificial light in close ecosystems. December, Miyazaki, Proc. International Workshop on Sweetpotato Production System toward the 21st Century (ed. by LaBonte, D. R., Yamashita, M., Mochida, H.) p 201-214.

Kozai, T. 1999. Advantages and disadvantages of closed-type over opened-type transplant production system. In "Develop- ment and Application of Closed-type Transplant Production System for Solving the Global Issues" (ed. by Kozai, T.), Yokendo, Tokyo, p 69-75.

Kubota, C., Kozai, T. 2001. Mathematical models for planning vegetative propagation under controlled environments. HortScience 36 : 15-19.

Liu, A., Latimer, J. G. 1995. Root cell volume in the planter flat affects watermelon seedling development and fruit yield. HortScience 30 : 242-246.

Lok, Y. H., Ohyama, K., Kubota, C., Kozai, T. 2002a. Sweetpotato propagule production rate and electric energy consumption in a closed transplant production system as affected by planting density. (Japanese text with English abstract) J. High Tech. Agric. 14 : 10-17.

Lok, Y. H., Ohyama, K., Kubota, C., Chintakovid, W., Kozai, T. 2002 b. Sweetpotato propagule production rate and electric energy consumption in a closed transplant production system as affected by propagation method. (Japanese text with English abstract) Environ. Control in Biol. 40 : 311-316.

McConnaughay, K. D. M., Berntson, G. M., Bazzaz, F, A. 1993. Limitations to $\mathrm{CO}_{2}$-induced growth enhancement in pot studies. Oecologia 94 : 550-557.

Nicola, S., Cantliffe, D. J. 1996. Increasing cell size and reducing medium compression enhance lettuce transplant quality and field production. HortScience 31 : 184-189.

Oda, M., Takato, J., Ikeda, H., Furukawa, H. 2002. Effects of cell volume at raising lettuce plugs on growth, sugar concentration and root respiration immediately before and after planting. (Japanese text with English abstract) Hortic. Res. (Japan) 1 : 27-30.

Ohyama, K., Yoshinaga, K., Kozai, T. 2000. Energy and mass balance of a closed-type transplant production system (1) Energy balance. (Japanese text with English abstract) J. High Tech. Agric. 12 : 160-167.

Richards, D., Rowe, R. N. 1977. Effects of root restriction, root pruning and 6-benzylaminopurine on the growth of peach seedlings. Ann. Bot. 41 : 729-740.

Ruff, M. S., Krizek, D. T., Mirecki, R. M., Inouye, D. W. 1987. Restricted root zone volume : Influence on growth and development of tomato. J. Am. Soc. Hortic. Sci. 112 : 763-769.

Yabuki, K., Kitaya, Y. 1984. Studies on the control of gaseous environment in the rhizosphere (1) Changes in $\mathrm{CO}_{2}$ concentration and gaseous diffusion coefficient in soils after irrigation. (Japanese text with English abstract) J. Agric. Meteorol. 40 : 17.

Yoshida, T., Hozyo, Y., Murata, T. 1970. Studies on the development of tuberous roots in sweet potato (Ipomea batatas, Lam. var edulis, Mak.). The effect of deep placement of mineral nutrients on the tuber-yield of sweet potato. (Japanese text with English abstract) Jpn. J. Crop Sci. 39 : 105-110. 